\title{
Hubungan Umur, Jenis Kelamin dan Perlakuan Penatalaksanaan dengan Ukuran Tonsil pada Penderita Tonsilitis Kronis di Bagian THT-KL RSUP DR. M. Djamil Padang Tahun 2013
}

\author{
Annisa Oktaria Shalihat ${ }^{1}$, Novialdi ${ }^{2}$, Lili Irawati ${ }^{3}$
}

\begin{abstract}
Abstrak
Tonsilitis kronis adalah infeksi berulang yang paling sering terjadi pada tenggorok terutama pada usia anakanak dan remaja. Ukuran tonsil dan adenoid cenderung kecil pada usia $<7$ tahun, bertambah besar pada usia 7-15 tahun dan cenderung mengecil pada usia tua. Tujuan penelitian ini adalah menentukan hubungan umur, jenis kelamin dan perlakuan penatalaksanaan dengan ukuran tonsil pada penderita tonsilitis kronis di bagian THT-KL RSUP DR. M. Djamil Padang tahun 2013. Penelitian bersifat analitik dengan menggunakan teknik non probability sampling yakni purposive sampling sehingga didapatkan 149 penderita tonsilitis kronis dari data rekam medis RSUP Dr. M. Djamil Padang tahun 2013. Data yang diperoleh diolah secara komputerisasi. Hasil penelitian ini didapatkan distribusi frekuensi penderita tonsilitis kronis terbanyak berdasarkan umur pada kelompok umur 11-20 tahun 70 penderita (47,0\%), jenis kelamin perempuan 84 penderita (56,4\%), ukuran tonsil T3-T3 82 penderita (55\%) dan penatalaksanaan operatif 93 penderita $(62,4 \%)$. Ada hubungan yang bermakna antara umur dengan ukuran tonsil $(p=0,000)$, tidak ada hubungan yang bermakna antara jenis kelamin dengan ukuran tonsil $(p=0,806)$ dan ada hubungan yang bermakna antara perlakuan penatalaksanaan dengan ukuran tonsil $(p=0,010)$ pada penderita tonsilitis kronis di bagian THT-KL RSUP DR. M. Djamil Padang tahun 2013.
\end{abstract}

Kata kunci: tonsilitis kronis, ukuran tonsil, tatalaksana

\begin{abstract}
Chronic tonsillitis is recurrent infections in the throat, especially in the age of children and adolescents. The size of the tonsils and adenoids tend to be small at age $<7$ years, large increases in the age of 7-15 years and tends to shrink in old age. The objective of this study was to determine the relationship of age, gender and management treatment with tonsil size in patients with chronic tonsillitis in departement of ENT-HN at the DR. M. Djamil Padang General Hospital in 2013. Analytic research using non probability sampling technique that is purposive sampling to obtain 149 patients with chronic tonsillitis from data taken in the medical records department of DR. M. Djamil Padang General Hospital in 2013. Data were processed with computer. Results of this study showed that the distribution of most patients with chronic tonsillitis based on age in the age group 11-20 years 70 patients (47.0\%), female gender 84 patients (56.4\%), tonsil size T3-T3 82 patients (55\%) and operative management of 93 patients $(62.4 \%)$, There is significant relationship between age with tonsil size $(p=0.000)$, there is no significant relationship between gender with tonsil size $(p=0.806)$ and there is significant relationship between management treatment with tonsil size $(p=0.010)$ in patients with chronic tonsillitis in departement of ENT-HN at the DR. M. Djamil Padang General Hospital in 2013.
\end{abstract}

Keywords: chronic tonsillitis, tonsil size, treatment

Affiliasi penulis: 1. Pendidikan Dokter FK UNAND (Fakultas Kedokteran Universitas Andalas Padang), 2. Bagian THT-KL FK UNAND/RSUP DR. M. Djamil Padang, 3. Bagian Fisika FK UNAND
Korespondensi: Annisa Oktaria Shalihat, E-mail:

sherly_annisa23@ymail.com, Telp: 085364516102 


\section{PENDAHULUAN}

Tonsilitis adalah peradangan pada tonsil palatina yang merupakan bagian dari cincin Waldeyer yang disebabkan oleh mikroorganisme berupa virus, bakteri, dan jamur yang masuk secara aerogen atau foodborn. ${ }^{1,2}$ Berdasarkan waktu berlangsung (lamanya) penyakit, tonsilitis terbagi menjadi 2, yakni tonsilitis akut jika penyakit (keluhan) berlangsung kurang dari 3 minggu dan tonsilitis kronis jika inflamasi atau peradangan pada tonsil palatina berlangsung lebih dari 3 bulan atau menetap. 3,4 Infeksi terjadi terusmenerus karena kegagalan atau ketidaksesuaian pemberian antibiotic. ${ }^{5}$

Radang kronis pada tonsil masih menjadi problem kesehatan dunia. Di Amerika Serikat prevalensi tonsilitis kronis pada tahun 1995 adalah sebesar 7 per 1000 penduduk atau 0,7\%, di Norwegia $11,7 \%$, di Turki tonsilitis rekuren ditemukan pada $12,1 \%$ anak. ${ }^{6}$ Penelitian yang dilakukan di Malaysia di poli THT Rumah Sakit Sarawak selama 1 tahun dijumpai 8118 pasien dan jumlah penderita penyakit tonsilitis kronis menempati urutan keempat yakni sebanyak $657(8,1 \%)$ penderita. $^{7}$

Data medical record tahun 2010 di RSUP DR. M. Djamil Padang di bagian THT-KL subbagian laring faring ditemukan insiden tonsilitis sebanyak 465 dari 1110 kunjungan di Poliklinik subbagian laring faring dan yang menjalani tonsilektomi sebanyak 163 kasus. ${ }^{8}$

Bakteri penyebab tonsilitis kronis pada umumnya sama dengan tonsilitis akut yaitu bakteri aerob Gram positif (yang paling sering) dan Gram negatif. ${ }^{9}$ Tonsilitis dapat menyebar dari orang ke orang melalui kontak tangan, menghirup udara setelah seseorang dengan tonsilitis bersin atau berbagi peralatan seperti sikat gigi dari orang yang terinfeksi. Anak-anak dan remaja usia sekolah adalah yang paling mungkin untuk menderita tonsilitis, tetapi dapat menyerang siapa saja. Beberapa literatur menyebutkan tonsilitis kronis sering terjadi pada usia 5-20 tahun. ${ }^{10-12}$

Penelitian yang dilakukan di Rumah Sakit Sarawak di Malaysia pada periode Juli 2003 sampai Juni 2004, dari 657 penderita tonsilitis kronis didapatkan laki-laki sebesar 342 (52\%) dan perempuan 315 (48\%). ${ }^{7}$ Sedangkan penelitian yang dilakukan di Rumah Sakit Pravara di India dari 203 penderita tonsilitis kronis, sebanyak 98 (48\%) berjenis kelamin laki-laki dan 105 (52\%) berjenis kelamin perempuan. ${ }^{13}$ Menurut hasil penelitian terhadap kembar dua yang lahir tahun 1979 tidak ada bukti keterlibatan genetik terhadap jenis kelamin tertentu untuk menderita penyakit tonsilitis kronis. ${ }^{14}$

Penelitian Nurjannah tahun 2011, mendapatkan 35 penderita tonsilitis kronis ditemukan keluhan utama terbanyak yaitu sakit menelan sebanyak 24 penderita. $^{9}$ Tonsil dapat membesar bervariasi (T1-T4) pada penderita tonsilitis. Penelitian yang dilakukan di Denizli Turkey dari 1784 anak sekolah usia 4-17 tahun didapatkan data ukuran tonsil T1 sebanyak 62\%, T2 sebanyak 28,4\%, T3 sebanyak 3,3\%, dan T4 sebanyak 0,1\%. ${ }^{15}$ Penelitian yang dilakukan di RSUP H. Adam Malik Medan dari 80 penderita tonsilitis kronis pada tahun 2009 ditemukan ukuran tonsil terbanyak T2/T2 yaitu 33,8\%. ${ }^{16}$

Penatalaksanaan tonsilitis meliputi medikamentosa dan operatif. Terapi medikamentosa yaitu dengan pemberian antibiotika sesuai kultur ditujukan untuk mengatasi infeksi yang terjadi baik pada tonsilitis akut, maupun tonsilitis rekuren atau tonsilitis kronis eksaserbasi akut. ${ }^{8}$ Penelitian yang dilakukan di RSUP H. Adam Malik Medan dari 80 penderita tonsilitis kronis pada tahun 2009 penatalaksanaan medikamentosa dilakukan sebanyak $83,7 \%$ dan operatif sebanyak 16,3\%. ${ }^{16}$ Penatalaksanaan operatif dengan tindakan tonsilektomi dilakukan apabila terjadi infeksi berulang atau kronis, gejala sumbatan tenggorok serta kecurigaan neoplasma.

Ukuran tonsil dan adenoid sangat kecil ketika anak lahir. Jaringan adenoid dan tonsil cenderung kecil pada usia $<7$ tahun, bertambah besar pada usia 7-15 tahun dan cenderung mengecil usia tua. ${ }^{15,17}$ Penelitian yang melihat hubungan umur dengan ukuran tonsil pada penderita tonsilitis kronis diperoleh nilai $p$ sebesar $0,001 .{ }^{16}$ Ukuran tonsil hipertrofi dari beberapa penelitian ditemukan terbanyak pada jenis kelamin laki-laki. Hipotesis sementara menyebutkan beberapa kemungkinan, namun kesimpulan yang didapatkan masih belum jelas. ${ }^{18}$ Penelitian yang melihat hubungan jenis kelamin dengan ukuran tonsil pada penderita tonsilitis kronis diperoleh nilai $p$ 
sebesar $0,112 .^{16}$ Penatalaksanaan tonsilitis kronis dengan tindakan operatif harus mempertimbangakan indikasi absolut dan indikasi relatif. Pada tonsil hipertrofi dapat menyebabkan keadaan emergency berupa obstruksi saluran napas yang merupakan indikasi absolut untuk tindakan tonsilektomi. Penelitian yang melihat hubungan perlakuan penatalaksanaan dengan ukuran tonsil pada penderita tonsilitis kronis diperoleh nilai $p$ sebesar $0,000 .^{16}$

Tonsilitis kronis merupakan penyakit yang paling sering terjadi dari seluruh penyakit tenggorok yang berulang. Data mengenai tonsilitis kronis di Indonesia masih sedikit. Sampai saat ini data mengenai penderita tonsilitis kronis di RSUP DR. M. Djamil Padang masih terbatas. Hal inilah yang mendorong perlu diteliti tentang hubungan umur, jenis kelamin dan perlakuan penatalaksanaan dengan ukuran tonsil pada penderita tonsilitis kronis di bagian THT-KL RSUP DR. M. Djamil Padang tahun 2013.

\section{METODE}

Sampel pada penelitian ini adalah pasien yang berobat di poliklinik dan instalansi rawat inap THT-KL RSUP DR. M. Djamil Padang yang didiagnosis oleh dokter spesialis THT-KL sebagai tonsilitis kronis dan tercatat di rekam medis selama periode 1 Januari - 31 Desember 2013. Penelitian ini bersifat analitik dengan teknik pengambilan sampel non probability sampling yaitu purposive sampling. Pengolahan data dilakukan dengan uji kemaknaan chi-square. Hasil analisis statistik dikatakann bermakna bila didapatkan $p \leq 0,05$ dengan menggunakan sistem komputerisasi. Variabel independennya adalah umur, jenis kelamin dan perlakuan penatalaksanaan. Variabel dependennya adalah ukuran tonsil yang memakai kriteria Brodsky.

HASIL

Tabel 1. Distribusi frekuensi penderita tonsilitis kronis berdasarkan umur

\begin{tabular}{rcc}
\hline Kelompok Usia & $\mathbf{f}$ & $\%$ \\
\hline $0-10$ tahun & 44 & 29,5 \\
$11-20$ tahun & 70 & 47,0 \\
$21-30$ tahun & 16 & 10,7 \\
$31-40$ tahun & 12 & 8,1 \\
$41-50$ tahun & 3 & 2,0 \\
$>50$ tahun & 4 & 2,7 \\
\hline Total & 149 & 100
\end{tabular}

Kebanyakan penderita tonsilitis kronis berada pada kelompok usia 11 - 20 tahun, yaitu sebanyak 70 penderita $(47,0 \%)$.

Tabel 2. Distribusi frekuensi penderita tonsilitis kronis berdasarkan jenis kelamin

\begin{tabular}{ccc}
\hline Jenis Kelamin & $\mathbf{f}$ & $\%$ \\
\hline Laki-laki & 65 & 43,6 \\
Perempuan & 84 & 56,4 \\
\hline Total & 149 & 100 \\
\hline
\end{tabular}

Penderita tonsilitis kronis banyak ditemukan pada jenis kelamin perempuan, yaitu sebanyak 84 penderita $(56,4 \%)$.

Tabel 3. Distribusi frekuensi penderita tonsilitis kronis berdasarkan keluhan utama

\begin{tabular}{lcc}
\hline \multicolumn{1}{c}{ Keluhan Utama } & $\mathbf{f}$ & $\%$ \\
\hline Nyeri atau sakit menelan & 108 & 72,5 \\
Susah menelan & 3 & 2,0 \\
Rasa mengganjal di tenggorok & 16 & 10,7 \\
Sering demam, batuk, pilek & 7 & 4,7 \\
Obstructive sleep apnea (OSA) & 3 & 2,0 \\
dll & 12 & 8,1 \\
\hline \multicolumn{1}{c}{ Total } & 149 & 100 \\
\hline
\end{tabular}

Keluhan utama yang sering dikeluhkan penderita tonsilitis kronis adalah nyeri atau sakit menelan, yaitu sebanyak 108 penderita $(72,5 \%)$.

Tabel 4. Distribusi frekuensi penderita tonsilitis kronis berdasarkan ukuran tonsil hipertrofi dan non hipertrofi

\begin{tabular}{ccc}
\hline Ukuran Tonsil & $\mathbf{f}$ & $\%$ \\
\hline Tonsil Hipertrofi & 112 & 75,2 \\
Tonsil non hipertrofi & 37 & 24,8 \\
\hline Total & 149 & 100 \\
\hline
\end{tabular}

Penderita tonsilitis kronis terbanyak dengan ukuran tonsil hipertrofi, yaitu sebanyak 112 penderita $(75,2 \%)$.

Tabel 5. Distribusi frekuensi penderita tonsilitis kronis berdasarkan frekuensi menderita sakit tenggorok

\begin{tabular}{ccc}
\hline Menderita sakit tenggorok & $\mathbf{f}$ & $\%$ \\
\hline$\geq 7 x /$ thn & 92 & 61,7 \\
$\pm 5 x /$ thn & 19 & 12,8 \\
$\leq 3 x /$ thn & 38 & 25,5 \\
\hline Total & 149 & 100 \\
\hline
\end{tabular}


Frekuensi menderita sakit tenggorok banyak dialami penderita tonsilitis kronis lebih atau sama 7 kali episode dalam satu tahun, yaitu sebanyak 92 penderita $(61,7 \%)$.

Tabel 6. Distribusi frekuensi penderita tonsilitis kronis berdasarkan penatalaksanaan

\begin{tabular}{ccc}
\hline Penatalaksanaan & $\mathbf{f}$ & $\%$ \\
\hline Medikamentosa & 56 & 37,6 \\
Operatif & 93 & 62,4 \\
\hline Total & 149 & 100 \\
\hline
\end{tabular}

Penatalaksanaan terbanyak pada penderita tonsilitis kronis adalah operatif, yaitu sebanyak 93 penderita $(62,4 \%)$.

Peningkatan dan penurunan setiap ukuran tonsil berdasarkan umur penderita tonsilitis kronis dapat dilihat pada Gambar 1.

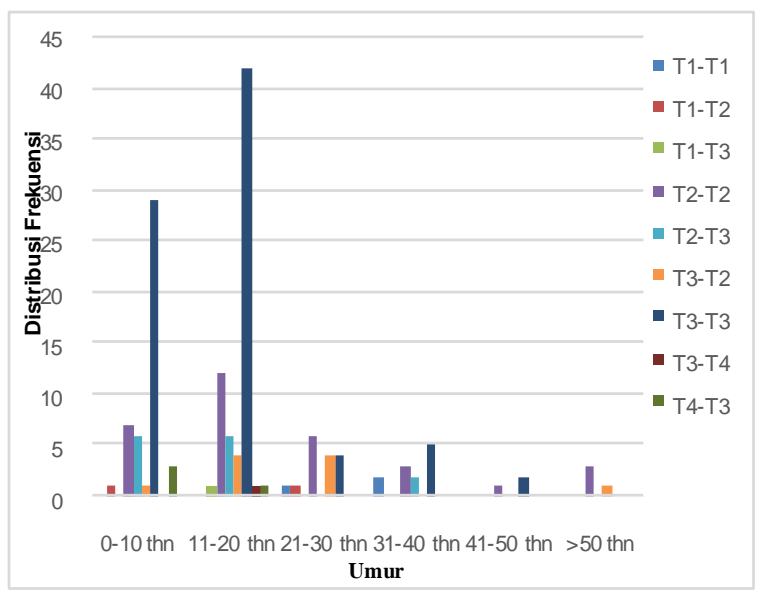

Gambar 1. Distribusi frekuensi umur dengan ukuran tonsil pada penderita tonsilitis kronis

Tabel 7. Hubungan antara umur dengan ukuran tonsil pada penderita tonsilitis kronis

\begin{tabular}{cccccccc}
\hline & \multicolumn{3}{c}{ Ukuran Tonsil } & & & \\
\cline { 2 - 7 } $\begin{array}{c}\text { Kelompok } \\
\text { Usia }\end{array}$ & Hipertrofi & \multicolumn{2}{c}{$\begin{array}{c}\text { Non } \\
\text { hipertrofi }\end{array}$} & & Total & $\mathbf{p}$ \\
& & & & & \\
\cline { 2 - 7 } & $\mathbf{f}$ & $\%$ & $\mathbf{f}$ & $\%$ & $\mathbf{f}$ & $\%$ & \\
\hline$\leq 18$ tahun & 89 & 84,8 & 16 & 15,2 & 105 & 100 & 0,00 \\
$>18$ tahun & 23 & 52,3 & 21 & 47,7 & 44 & 100 & \\
\hline Total & 112 & 75,2 & 37 & 24,8 & 149 & 100 & \\
\hline
\end{tabular}

Uji chi-square diperoleh $p=0,000$ yang menunjukkan terdapat hubungan yang bermakna secara statistik antara umur dengan ukuran tonsil pada penderita tonsilitis kronis.

Tabel 8. Hubungan antara jenis kelamin dengan ukuran tonsil pada penderita tonsilitis kronis

\begin{tabular}{|c|c|c|c|c|c|c|c|}
\hline \multirow{3}{*}{$\begin{array}{c}\text { Jenis } \\
\text { Kelamin }\end{array}$} & \multicolumn{4}{|c|}{ Ukuran Tonsil } & & & \multirow[b]{2}{*}{$\mathrm{p}$ value } \\
\hline & \multicolumn{2}{|c|}{ Hipertrofi } & \multicolumn{2}{|c|}{ Non hipertrofi } & \multicolumn{2}{|c|}{ Total } & \\
\hline & $f$ & $\%$ & $f$ & $\%$ & $f$ & $\%$ & \\
\hline Laki-laki & 50 & 76,9 & 15 & 23,1 & 65 & 100 & 0,806 \\
\hline Perempuan & 62 & 73,8 & 22 & 26,2 & 84 & 100 & \\
\hline Total & 112 & 75,2 & 37 & 24,8 & 149 & 100 & \\
\hline
\end{tabular}

Dari uji chi-square diperoleh $\mathrm{p}$ value 0,806 yang menunjukkan tidak terdapat hubungan yang bermakna secara statistik antara jenis kelamin dengan ukuran tonsil pada penderita tonsilitis kronis.

Tabel 9. Hubungan antara Perlakuan Penatalaksanaan dengan Ukuran Tonsil pada Penderita Tonsilitis Kronis

\begin{tabular}{|c|c|c|c|c|c|c|c|}
\hline \multirow{3}{*}{ Tatalaksana } & \multicolumn{4}{|c|}{ Ukuran Tonsil } & \multicolumn{2}{|c|}{ Total } & \multirow{2}{*}{ p } \\
\hline & \multicolumn{2}{|c|}{ Hipertrofi } & \multicolumn{2}{|c|}{$\begin{array}{c}\text { Non } \\
\text { hipertrofi }\end{array}$} & & & \\
\hline & $f$ & $\%$ & $f$ & $\%$ & $f$ & $\%$ & \\
\hline Medikamentosa & 35 & 62,5 & 21 & 37,5 & 56 & 100 & 0,010 \\
\hline Operatif & 77 & 82,8 & 16 & 17,2 & 93 & 100 & \\
\hline Total & 112 & 75,2 & 37 & 24,8 & 149 & 100 & \\
\hline
\end{tabular}

Dari uji chi-square diperoleh $p=0,010$ yang menunjukkan terdapat hubungan yang bermakna secara statistik antara perlakuan penatalaksanaan dengan ukuran tonsil pada penderita tonsilitis kronis.

\section{PEMBAHASAN}

\section{Gambaran penderita tonsilitis kronis}

Penderita tonsilitis kronis pada penelitian ini paling banyak terdapat pada kelompok usia 11-20 tahun, yaitu sebanyak 70 penderita (47,0\%). Fungsi imunologi tonsil sangat aktif antara umur 3-10 tahun. Fungsi tonsil akan meningkat pada umur 5 tahun kemudian menurun dan akan mengalami peningkatan lagi pada umur 10 tahun, kemudian akan menurun pada umur 15 tahun karena tonsil mulai mengalami involusi pada saat pubertas sehingga produksi antibodi berkurang yang membuat lebih rentan terhadap infeksi. Karena itu anak-anak dan remaja usia 5-15 tahun (usia sekolah), yang lebih banyak 
menghabiskan waktu di lingkungan sekolah dan di luar ruangan, sering menderita ISPA. ${ }^{19}$ Anak-anak dan remaja usia sekolah juga sering mengosumsi makanan ringan yang mengandung bahan pengawet, pemanis buatan dan pewarna buatan serta minuman dingin yang dapat menimbulkan iritasi ditenggorok sehingga dapat memicu timbulnya infeksi tenggorok ataupun infeksi tonsil. ${ }^{20}$ Tingginya kejadian tonsilitis kronis pada anak-anak dan remaja dikarenakan mereka sering menderita ISPA atau tonsilitis akut yang tidak diterapi dengan adekuat atau dibiarkan saja tanpa pengobatan. ${ }^{4}$ Tonsilitis dapat menyebar melalui kontak tangan maupun udara sehingga anak-anak dan remaja berusia 5-15 tahun adalah yang paling mungkin untuk menderita tonsilitis, tetapi dapat menyerang siapa saja, ${ }^{10}$ sehingga pada penelitian ini juga ditemukan penderita usia $<5$ tahun dan $>15$ tahun.

Sebanyak $84(56,4 \%)$ penderita tonsilitis kronis adalah perempuan. Faktor predisposisi tonsilitis kronis antara lain iritasi kronis (akibat rokok dan makanan), gizi atau daya tahan tubuh yang rendah, pengaruh cuaca dan hiegine mulut yang buruk. ${ }^{4}$ Pada masa pubertas dimana kebutuhan kalori dan protein meningkat, perempuan terutama usia remaja lebih mementingkan bentuk tubuh dan penampilan sehingga banyak dari mereka yang menunda jadwal makan bahkan mengurangi porsi makanan dari yang dianjurkan agar tampak sempurna postur tubuhnya. Hal ini dapat menyebabkan kekurangan gizi dan daya tahan tubuh terhadap serangan berbagai penyakit menjadi sangat rendah sehingga lebih banyak mengalami masalah kesehatan. ${ }^{21}$ Selain itu pada perempuan terutama anak-anak perempuan cenderung beraktifitas di tempat yang bersih terutama di dalam ruangan dan kurang beradaptasi dengan lingkungan kotor yang banyak mengandung mikroorganisme. Hal ini menyebabkan daya tahan tubuh mereka tidak berkembang secara sempurna sehingga sulit mengatasi infeksi dan masalah kesehatan yang lain. ${ }^{22}$ Banyaknya penderita tonsilitis kronis pada jenis kelamin perempuan dikarenakan perempuan lebih memperhatikan kesehatan dan mencari pengobatan serta sensitif terhadap rangsangan nyeri. Namun, perbedaan jenis kelamin pada tonsilitis kronis dan rekuren tidak dapat dijelaskan setelah 30 tahun diobservasi. ${ }^{23}$

Penderita tonsilitis kronis sebanyak 108 penderita $(72,5 \%)$ memiliki keluhan utama nyeri atau sakit menelan. Keluhan utama yang diutarakan penderita tonsilitis kronis beragam karena gejala tonsilitis kronis bervariasi, gejala lokal yaitu rasa tidak nyaman pada tenggorokan akibat adanya pembesaran ukuran tonsil sehingga ada rasa mengganjal di tenggorok, susah menelan dan nyeri atau sakit menelan karena radang tonsil yang berulang. Gejala sistemis yaitu rasa tidak enak badan, nyeri kepala, demam, nyeri otot dan persendian. Gejala klinis yaitu tonsil dengan kripta melebar, plika tonsilaris anterior hiperemis, pembengkakan kelenjar limfe regional dan hipertrofi tonsil yang dapat menyebabkan obstructive sleep apnea (OSA) dengan gejala mendengkur/ mengorok ketika tidur, terbangun tiba-tiba karena sesak atau henti nafas, sering mengantuk, gelisah, perhatian berkurang dan prestasi belajar menurun. ${ }^{4,23}$ Tonsilitis kronis dapat juga terjadi karena penyebaran infeksi kronis dari tempat lain yang berhubungan dengan rongga tenggorok. Jadi pada penelitian ini juga didapatkan keluhan utama hidung tersumbat sampai sulit bernafas, telinga berdengung, telinga pekak, telinga berair dan telinga bernanah. Banyaknya ditemukan keluhan utama nyeri atau sakit menelan pada penelitian ini karena ada beberapa penderita datang dengan tonsilitis kronis eksaserbasi akut, tonsil dalam keadaan radang akut menyebabkan nyeri atau sakit ketika menelan. Penderita juga sebagian besar mengalami radang tonsil berulang dengan frekuensi $\geq 7 x /$ thn. Jain menyatakan bahwa tonsilitis biasanya dimulai dengan sakit tenggorok mendadak dan nyeri menelan. ${ }^{24}$ Leschann juga menyatakan bahwa sakit menelan adalah indikator paling awal dari tonsilitis dan sangat khas. ${ }^{25}$

Ukuran tonsil T3-T3 adalah yg paling banyak ditemukan pada penderita tonsilitis kronis yaitu sebanyak 82 penderita $(55,0 \%)$ dan tonsil hipertrofi ( $\geq$ T3) sebanyak 112 penderita (75,2\%). Tonsil merupakan jaringan limfoid yang berperan membantu sistem imunitas. Pada tonsilitis kronis terjadi infeksi yang menetap atau berulang. Tonsil yang berulang kali terkena infeksi suatu saat tidak dapat membunuh 
semua kuman, akibatnya kuman bersarang di dalam tonsil (fokal infeksi). Adanya infeksi berulang dan fokal infeksi menyebabkan tonsil bekerja keras melawan kuman dengan memproduksi sel-sel imun yang banyak sehingga ukuran tonsil akan membesar dengan cepat melebihi ukuran normal. ${ }^{4}$ Pada tonsilitis kronis terjadi infiltrasi limfosit ke epitel permukaan tonsil. Peningkatan jumlah sel plasma di dalam subepitel maupun di dalam jaringan interfolikel. Hiperplasia dan pembentukan fibrosis dari jaringan ikat parenkim dan jaringan limfoid mengakibatkan terjadinya hipertrofi tonsil. ${ }^{26}$ Ukuran tonsil hipertrofi dapat menimbulkan berbagai keluhan dan gejala seperti rasa tidak nyaman atau rasa mengganjal di tenggorokan, kesulitan menelan dan terutama bisa menyebabkan obstruksi saluran nafas yang ditandai dengan tidur mendengkur, sering mengantuk, gelisah, perhatian kurang dan prestasi belajar menurun. $\mathrm{Hal}$ inilah yang biasanya mendorong pasien untuk mencari pengobatan. ${ }^{4}$

Frekuensi menderita sakit tenggorok pada penderita tonsilitis kronis yang tersering adalah $\geq 7 x /$ thn yaitu sebanyak 92 penderita (61,7\%). Frekuensi menderita sakit tenggorok dapat menjadi salah satu pertimbangan untuk melakukan tindakan operatif jika terjadi 7 kali atau lebih dalam 1 tahun, atau 5 kali dalam 1 tahun selama 2 tahun, atau 3 kali dalam 1 tahun selama 3 tahun berturut-turut. ${ }^{3}$ Tonsil yang menjadi sarang infeksi akan mudah mengalami infeksi berulang jika ada iritasi pada tenggorok atau tonsil. Makanan yang terlalu pedas, terlalu asam, terlalu panas atau dingin dan makanan-makanan yang terlalu bergetah serta kebiasaan merokok dapat menimbulkan iritasi ditenggorok yang dapat memicu timbulnya infeksi tenggorok ataupun infeksi tonsil. ${ }^{20}$ Pada penderita yang alergi terhadap obat-obatan tertentu, cuaca, debu, makanan dan minuman seringkali mengalami infeksi berulang karena bila alergi tidak dikendalikan akan mengakibatkan daya tahan tubuh menurun dan mudah terserang infeksi saluran nafas khususnya tonsilitis. Bila infeksi yang menyebabkan batuk, pilek atau demam seringkali berulang setiap bulan atau bahkan sebulan dua kali, maka akibat yang paling sering terjadi adalah tonsil membesar hingga mengganggu pernapasan dan gangguan tidur. ${ }^{3}$
Tindakan operatif adalah penatalaksanaan yang paling banyak dilakukan pada penderita tonsilitis kronis yaitu sebanyak 93 penderita $(62,4 \%)$, diikuti oleh medikamentosa sebanyak 56 penderita (37,6\%).. Pada tonsilitis rekuren dan tonsilitis kronis bakteri penyebab kebanyakan berasal dari bakteri yang terdapat di parenkim tonsil dibandingkan dengan permukaan tonsil, sehingga swab dari permukaan tonsil bisa saja keliru. ${ }^{8}$ Terapi antibiotik pada tonsilitis kronis sering gagal dalam mengurangi dan mencegah rekurensi infeksi, baik karena kegagalan penetrasi antibiotik ke dalam parenkim tonsil ataupun ketidaktepatan antibiotik. ${ }^{9}$ Penatalaksanaan operatif dengan tindakan tonsilektomi (pengangkatan tonsil palatina) dilakukan apabila terjadi infeksi berulang atau kronis, gejala sumbatan serta kecurigaan neoplasma. ${ }^{1}$ Tonsilektomi merupakan prosedur yang paling sering dilakukan terutama pada anak-anak. Pada dekade terakhir ini, tonsilektomi tidak hanya dilakukan untuk tonsilitis berulang, namun juga untuk berbagai kondisi yang lebih luas termasuk kesulitan makan, tounge thrust, halitosis, mendengkur, dan gangguan bicara. ${ }^{27}$ Tonsilektomi perlu dipetimbangkan bila ada keyakinan tonsil sebagai fokus infeksi dan gagal dieradikasi dengan terapi antibiotika yang adekuat. Tindakan tonsilektomi dilakukan setelah meneliti kembali kegagalan pengobatan dengan antibiotika standar. Kegagalan terapi dapat pula diakibatkan karena organisme yang ada telah membentuk koloni yang tidak responsif terhadap terapi, organisme resisten terhadap terapai antibiotika standar atau penderita tidak patuh minum obat sesuai takaran. ${ }^{23}$

Tonsilektomi harus dengan indikasi tepat mengingat peranan tonsil sebagai bagian sistem pertahanan tubuh. Penelitian Amarudin dan Christanto menunjukkan bahwa pada tonsilitis rekuren atau kronis, tonsilektomi menurunkan kejadian sakit tenggorok, meningkatkan quality of life (QOL), menurunkan pemakaian fasilitas kesehatan dan meminimalkan beban ekonomi. Pada anak-anak tonsilektomi hendaknya dilakukan pada tonsilitis kronis yang telah mengganggu fungsi normal seperti obstructive sleep apnea syndrome (OSAS) dan gangguan digesti. ${ }^{23}$ Kebanyakan pada penderita dewasa yang mendapat tindakan tonsilektomi 
dikarenakan adanya infeksi kronis. Anak-anak dan orang dewasa yang mendapatkan tindakan tonsilektomi mengurangi episode dan durasi keluhan pada tenggorok. Indikasi tonsilektomi mungkin dapat berdasarkan terdapat dan beratnya satu atau lebih gejala, dan penderita seperti ini harus mempertimbangkan untuk tindakan tonsilektomi karena gejala tersebut dapat mempengaruhi kualitas hidup walaupun tidak mengancam nyawa. ${ }^{16,27}$

\section{Hubungan umur dengan ukuran tonsil pada penderita tonsilitis kronis}

Tonsil hipertrofi pada penelitian ini lebih banyak ditemukan pada penderita tonsilitis kronis yang berumur $\leq 18$ tahun yaitu sebanyak 89 penderita $(84,8 \%)$ sedangkan tonsil non hipertrofi banyak ditemukan pada umur >18 tahun yaitu 21 (47,7\%). Setelah dilakukan uji statistik dengan analisis chisquare diperoleh nilai $p$ sebesar 0,000 . Hal ini menunjukkan terdapat hubungan yang bermakna antara umur dengan ukuran tonsil pada penderita tonsilitis kronis. Hal serupa juga diperoleh dari penelitian Amalia yang mendapatkan $p=0,001$ yang menunjukkan terdapat hubungan yang bermakna antara umur dengan ukuran tonsil pada penderita tonsilitis kronis. ${ }^{16}$ Aktivitas imun tonsil paling maksimal antara umur 3 sampai 10 tahun, karena itu ukuran tonsil paling besar pada usia anak. Tonsil mulai mengalami involusi secara bertahap pada saat pubertas. ${ }^{4}$ Hal ini sesuai dengan grafik 2 yang menggambarkan aktivitas imun tonsil terlihat dari ukuran tonsil yang membesar meningkat pada umur 11-20 tahun dan kemudian mengalami penurunan ukuran sejalan bertambahnya usia. Penelitian Akcay et al didapatkan pada anak sekolah dengan ukuran tonsil T2 dan T3 menunjukkan penurunan jumlah sejalan dengan bertambahnya umur. ${ }^{15}$ Crombie dan Barr pada menyatakan adanya kecenderungan ukuran tonsil relatif kecil pada umur $<7$ tahun dan membesar pada umur 7-15 tahun, sedangkan pada usia tua memiliki ukuran tonsil yang kecil. ${ }^{17}$

\section{Hubungan jenis kelamin dengan ukuran tonsil pada penderita tonsilitis kronis}

Ukuran tonsil hipertrofi banyak ditemukan pada perempuan yaitu sebanyak 62 penderita $(73,8 \%)$ dan tonsil non hipertrofi juga banyak ditemukan pada perempuan yaitu sebanyak 22 penderita (26,2\%). Setelah dilakukan uji statistik dengan analisis chisquare diperoleh nilai $p$ value sebesar 0,806 . Hal ini menunjukkan tidak terdapat hubungan yang bermakna antara jenis kelamin dengan ukuran tonsil pada penderita tonsilitis kronis. Penelitian Amalia di RSUP H. Adam Malik Medan didapatkan $p$ value 0,112 yang menunjukkan tidak terdapat hubungan antara jenis kelamin dengan ukuran tonsil pada tonsilitis kronis. ${ }^{16}$ Akcay et al menyebutkan bahwa jenis kelamin laki-laki mungkin menjadi salah satu faktor risiko terjadinya hipertrofi tonsil. ${ }^{15} \mathrm{Hal}$ ini mungkin dikarenakan faktor iritasi kronis, kebiasaan merokok dan sering makan, pada laki-laki yang menyebabkan infeksi berulang pada tonsil sehingga terjadi pembesaran tonsil. ${ }^{4}$ Jenis kelamin perempuan, terutama anak-anak perempuan yang kurang beradaptasi dengan lingkungan kotor membuat daya tahan tubuh tidak berkembang sempurna dan remaja perempuan yang lebih memperhatikan bentuk tubuh dan penampilan sehingga menunda jadwal makan bahkan menggurangi porsi makanan sehingga membuat daya tahan tubuh rendah. Hal ini dapat membuat perempuan lebih rentan terhadap infeksi tonsilitis berulang sehingga terjadi pembesaran tonsil. ${ }^{21-22}$

\section{Hubungan perlakuan penatalaksanaan dengan ukuran tonsil pada penderita tonsilitis kronis}

Perlakuan penatalaksanaan operatif pada penelitian ini lebih banyak pada penderita tonsilitis kronis yang memilki ukuran tonsil hipertrofi yaitu sebanyak 77 penderita (82,8\%), sedangkan untuk tonsil non hipertrofi lebih banyak diberikan terapi medikamentosa yaitu sebanyak 21 penderita (37,5\%). Setelah dilakukan uji statistik dengan analisis chisquare diperoleh nilai $p$ sebesar 0,010 . Hal ini menunjukkan terdapat hubungan yang bermakna antara perlakuan penatalaksanaan dengan ukuran tonsil pada penderita tonsilitis kronis. Penelitian yang dilakukan Amalia mendapatkan $p$ sebesar 0,000 menunjukkan terdapat hubungan yang bermakna antara perlakuan penatalaksanaan dengan ukuran tonsil pada penderita tonsilitis kronis. ${ }^{16}$ Indikasi operatif (tonsilektomi) dulu dan sekarang tidak berbeda, namun terdapat perbedaan prioritas relatif dalam 
menentukan indikasi tonsilektomi pada saat ini. Dulu tonsilektomi diindikasikan untuk terapi tonsilitis kronis dan berulang. Saat ini, indikasi yang lebih utama adalah obstruksi saluran nafas dan tonsil hipertrofi. Pada tonsil hipertrofi yang menyebabkan keadaan emergency seperti adanya obstruksi saluran nafas, indikasi tonsilektomi sudah tidak diperdebatkan lagi, sudah menjadi indikasi absolut. ${ }^{28}$ Pada tonsil hipertrofi yang menyebabkan obstructive sleep apnea (OSA) terdapat gejala yang mengganggu kualitas hidup seperti mendengkur atau menggorok ketika tidur, sering mengantuk, gelisah, perhatian berkurang dan prestasi belajar menurun. ${ }^{4}$ Karena itu kebanyakan penderita tonsilitis kronis pada penelitian ini mendapatkan tindakan tonsilektomi.

Penderita tonsilitis kronis dengan tonsil hipertrofi pada penelitian ini tidak semuanya mendapatkan tindakan tonsilektomi, ada juga yang mendapatkan terapi medikamentosa. Hal ini karena beberapa penderita datang dengan diagnosis tonsilitis kronis ekserbasi akut (infeksi aktif) yang merupakan kontraindikasi relatif untuk tonsilektomi. Pada penderita tonsilitis kronis dengan tonsil non hipertrofi pada penelitian ini ada juga yang mendapatkan tindakan tonsilektomi. Hal ini karena penderita mengalami frekuensi menderita sakit tenggorok $\geq 7 x /$ thn dalam 1 tahun atau $5 x /$ thn dalam 2 tahun atau $3 x /$ thn dalam 3 tahun yang merupakan indikasi tonsilektomi. ${ }^{29}$

\section{KESIMPULAN}

Berdasarkan hasil penelitian terhadap penderita tonsilitis kronis di bagian THT-KL RSUP DR. M. Djamil Padang periode 1 Januari - 31 Desember 2013 didapatkan penderita tonsilitis kronis berdasarkan umur terbanyak adalah pada kelompok usia 11-20 tahun, jenis kelamin yang terbanyak adalah perempuan, keluhan utama yang sering ditemukan adalah nyeri atau sakit menelan, ukuran tonsil yang sering ditemukan adalah T3-T3 dan terbanyak tonsil hipertrofi ( $\geq T 3$ pada salah satu tonsil), frekuensi menderita sakit tenggorok yang terbanyak adalah $\geq 7 x /$ thn, dan penatalaksanaan yang banyak dilakukan adalah operatif. Terdapat hubungan bermakna antara umur dengan ukuran tonsil, antara perlakuan penatalaksanaan dengan ukuran tonsil dan tidak terdapat hubungan bermakna antara jenis kelamin dengan ukuran tonsil pada penderita tonsilitis kronis.

\section{DAFTAR PUSTAKA}

1. Rusmarjono, Soepardi EA. Faringitis, tonsilitis, dan hipertrofi adenoid. Buku Ajar Telinga Hidung Tenggorokan Kepala \& Leher. Jakarta: Badan Penerbit FKUI. 2011. hlm. 217-25.

2. Siswantoro B. Pengaruh tonsilektomi terhadap kejadian bakteremia pasca operasi. Semarang: Universitas Diponegoro; 2003.

3. Judarwanto W. Operasi amandel atau tonsilektomi: komplikasi dan kontroversi indikasi. Indonesian Children dalam Koran Indonesia Sehat [serial online] 2010 (diunduh 17 September 2013). Tersedia dari: URL : HYPERLINK http://koran indonesiasehat.wordpress.com.

4. Farokah. Hubungan tonsilitis kronis dengan prestasi belajar pada siswa kelas II sekolah dasar di Kota Semarang. Semarang: Universitas Diponegoro; 2005.

5. Raju G, Selvam EM. Evaluation of microbial flora in chronic tonsilitis and the role of tonsillectomy. Bangladesh J Otorhinolaryngol. 2012;18(2):109-13.

6. Novel F. Pengaruh adenotonsilektomi terhadap tekanan telinga tengah dan kualitas hidup anak adenotonsilitis kronik dengan disfungsi tuba (tesis). Semarang: Universitas Diponegoro; 2010.

7. Sing TT. Pattren of otorhinolaryngology head and neck disease in outpatient clinic of a Malaysian hospital. Journal of Head and Neck Surgery. 2007; 2(1).

8. Novialdi, Pulungan MR. Mikrobiologi tonsilitis kronis. Padang: Universitas Andalas; 2012 (diunduh 4 Maret 2013). Tersedia dari: URL: HYPERLINK http://repository.unand.ac.id.

9. Nurjannah Z. Karakteristik penderita tonsilitis kronis di RSUP H. Adam Malik Medan tahun $2007-$ 2010. Medan: Universitas Sumatera Utara; 2011.

10. National Health Service. Tonsillitis. 2010 (diunduh 31 Agustus 2013). Tersedia dari: URL: HYPER LINK http://www.nhs.uk/Conditions/Tonsillitis.

11. Edgren AL, Davitson T. Sore throat. Journal of the American Assosiation. 2004;13:1664-78.

12. Kurien M, Stanis A, Job A, Brahmadathan, Thomas K. Throat swab in the chronic tonsillitis: how 
reliable and valid is it?. Singapore Med J. 2000; 41(7):324-6.

13. Awan Z, Hussain A, Bashir H. Statistical analysis of ear, nose, and throat (ENT) disease in pediatric population at PIMS, Islamabad: 10 years experience. Journal Medical Scient. 2009; 17(2):92-4.

14. Kvestad E, Kværner KJ, Røysamb E, Tambs K, Harris JR, Magnus P. Heritability of recurrent tonsillitis. Arch Otolaryngol Head Neck Surg. 2005; 131:383-7.

15. Akcay A, Kara CO, Dagdeviren E, Zencir M. Variation in tonsil size in 4 to 17 year old schoolchildren. The Journal of Otolaryngology. 2006;35(4):270-4.

16. Amalia N. Karakteristik penderita tonsilitis kronis di RSUP H. Adam Malik Medan tahun 2009 (tesis). Medan: Universitas Sumatera Utara; 2011.

17. Crombie IK, Barr G. An investigation into factors that may influence tonsil morphology. Journal of the Royal Society of Medicine. 1990;83:20-1.

18. Abouzied A, Emad M. Sex differences in tonsillitis. Dalhousie Medical Journal. 2008;35(1):8-11.

19. Shirley WP, Wolley AL, Wiatrak BJ. Pharyngitis and adenotonsillar disease. Dalam: Cummings Otolaryngology Head \& Neck Surgery. Philadelphia: Mosby Elsevier: 2010. hlm. 2784-5.

20. Jupri. Mengenali penyebab radang tenggorok dan pengobatannya. 2010 (diunduh 29 September 2014). Tersedia dari URL : HYPERLINK http:// jupri.wordpress.com/2010/03/28/mengenali-penye bab-radang-tenggorokan-dan-pengobatannya

21. Susanti E. Perbedaan asupan energi, protein berdasarkan jenis kelamin, tipe daerah dan pendapatan pada remaja usia 13-18 tahun di
Propinsi Nusa Tenggara Timur dan Sulawesi Tengah (Analisis Data Riskesdas Tahun 2010). Program Studi IImu Gizi, Fakultas IImu-IImu Kesehatan, Universitas Esa Unggul. 2013.

22. Clough. Hubungan antara kebersihan dengan tingkat penyakit kronis dan penyakit autoimun pada wanita. Oregon State University [serial online] 2011 (diunduh 29 September 2014). Tersedia dari URL : HYPERLINK http://www.npr.org/blogs/health/2011/ 02/04/133371076/how-keeping-little-girls-squeakyclean-could-make-them-sick.

23. Amarudin T, Christanto A. Kajian Manfaat Tonsilektomi. Cermin Dunia Kedokteran. 2007; (155):61-8.

24. Jain N. Tonsillitis treatment causes and symptom. 2009 (diunduh 17 September 2013). Tersedia dari: URL: HYPERLINK http://www.disabled-world.com/ health/pral/tonsillitis.

25. Leschmann T. Sign and symptoms tonsillitis. 2005 (diunduh 31 Agustus 2013). Tersedia dari: URL : HYPERLINK http://www.ehow.com/aboutsll0417 sign-symptoms-tonsillitis.

26. Ugras S, Kutluhan A. Chronic tonsillitis can be diagnosed with histopatologic findings. Europe Journal General Medical. 2008;5(2) :95-103.

27. Hermaini B. Tonsilektomi pada anak dan dewasa. health tecnology assessment (HTA) Indonesia. 2004.

28. Kartika H. Tonsilektomi. welcome \& joining otolaryngology in Indonesian. 2008 (diunduh 31 Agustus 2013). Tersedia dari: URL: HYPERLINK http://www.hennykartika.wordpress.com.

29. Ruckenstein MJ. Tonsillectomy. Dalam: Comprehensive Review of Otolaryngology. Philadelphia. 2004;1:136. 